\title{
PROJETO SER CRIANÇA: AVALIAÇÃO E RESULTADOS
}

\section{RESUMO}

Este artigo tem como objetivo avaliar o Projeto Ser Criança "Educação pelo Brinquedo", analisando os resultados por ele produzidos na formação social de crianças e adolescentes dele participantes. O Projeto tem sido implementado por uma organização do Terceiro Setor nas cidades de Curvelo e Araçuaí, em Minas Gerais. . Este artigo fundamenta-se em pesquisa descritiva que envolveu a análise de dados quantitativos e qualitativos advindos de fontes bibliográficas, documentais e entrevistas. Adotou-se o método de avaliação ex-post com foco nos impactos e resultados gerados pelo projeto com base em Albuquerque (2006). Foram utilizados os escores dos exames dos alunos de escolas públicas de ensino fundamental, realizados pelo Índice de Desenvolvimento da Educação Básica (IDEB), e dados obtidos nos relatórios técnicos elaborados pelos coordenadores e em 25 entrevistas que envolveram educadores, alunos, pais e egressos. Pelos resultados da pesquisa pode-se concluir que os alunos das escolas parceiras do Projeto apresentaram melhor desempenho escolar em comparação com aqueles obtidos pelos estudantes de outras escolas. A pesquisa revelou que o Projeto contribuiu na formação de crianças e jovens por meio de ações educativas inovadoras e de uma metodologia inclusiva.

Palavras-chave: Avaliação. Projetos Educativos. Terceiro Setor. Responsabilidade Social.

\section{BEING A CHILD PROJECT: EVALUATION AND RESULTS}

\begin{abstract}
This article aims to evaluate Projeto Ser Criança "Educação pelo Brinquedo", analyzing the results it produces in the social formation of children and adolescents of the participants. The Project has been implemented by a Third Sector organization in the cities of Curvelo and Araçuaí, in Minas Gerais. This article is based on descriptive research that involved the analysis of quantitative and qualitative data from bibliographic sources, documentaries and interviews. It was adopted the ex-post evaluation method with focus on the impacts and results generated by the project based on the considerations of Albuquerque (2006). The students' scores of public elementary schools, conducted by the Basic Education Development Index (IDEB), were used, and data obtained from the technical reports prepared by the coordinators and 25 interviews involving educators, students, parents and graduates were used. From the results of the research it can be concluded that the students of the partner schools of the Project presented better school performance compared to those obtained by students from other schools. The research revealed that the Project contributed to the training of children and young people through innovative educational actions and an inclusive methodology.
\end{abstract}

Keywords: Evaluation. Educational Projects. Third Sector. Social Responsibility.

Valter Moreira Rocha Junior ${ }^{1}$

Domingos Antônio Giroletti ${ }^{2}$

Reginaldo de Jesus Carvalho Lima ${ }^{3}$

\footnotetext{
${ }^{1}$ Mestre em Administração pela Fundação Pedro Leopoldo - FPL. Professor na Faculdade de Ciências Sociais Aplicadas de Belo Horizonte (FACISA/BH) e na Faculdade Arquidiocesana de Curvelo - FAC. Brasil. E-mail: valterrochajr@outlook.com

${ }^{2}$ Doutor em Antropologia Social pelo Museu Nacional da Universidade Federal do Rio de Janeiro - UFRJ. Professor do Mestrado Profissional de Administração da Fundação Pedro Leopoldo - FPL. Brasil. E-mail: domingosgiroletti@gmail.com

${ }_{3}^{3}$ Doutor em Administração pela Universidade Federal de Minas Gerais - UFMG. Professor e coordenador do curso de graduação em Administração da Fundação Pedro Leopoldo - FPL e professor do Mestrado Profissional em Administração da mesma instituição. Brasil. E-mail: regilima.jesus@ gmail.com
} 


\section{INTRODUÇÃO}

O campo de conhecimentos teóricos e práticos relacionado à avaliação de projetos sociais, políticas e programas tem despertado o interesse de número crescente de pesquisadores e diversos profissionais nas últimas décadas (Carvalho, 2001, Guba \& Lincoln, 2011, Jannuzzi, 2013, Marino, 2003a). Contudo, referindo-se ao contexto do início do século XXI, Carvalho (2001, p.67) chegou a afirmar "A avaliação de programas e projetos sociais é relativamente recente no Brasil."

Para Jannuzzi (2014, p.26) “A avaliação de programas tem recebido as mais diferentes definições na literatura especializada, segundo os diversos modelos conceituais, paradigmas teóricos e linhas de pesquisa da Ciência Política, Ciências Sociais, Economia e Administração Pública". Segundo o referido autor a avaliação pode envolver uma perspectiva mais geral na análise $\mathrm{e}$ instrumentalização de programas governamentais ou assumir caráter particular de investigação empírica acerca de programas e projetos sociais, como as avaliações de impacto.

A avaliação de projetos sociais contribui para melhorar sua qualidade, possibilitando sua correção e aprimoramento. Trata-se de um processo complexo que envolve ações vinculadas às fases de planejamento e implementação e, mais recentemente, tem sido considerada um "processo de construção permanente" (Carvalho, 2003, p.185). Outro aspecto importante refere-se à captação de recursos para a realização de projetos. Nesse sentido, a avaliação de projetos pode favorecer a obtenção de subvenções, na medida em que aumenta a racionalidade da gestão por meio da mensuração da eficiência, eficácia e equidade (Cohen \& Franco, 2012). É importante fazer a avaliação de projetos, para que as ações das entidades sejam mais transparentes e possam averiguar os serviços sociais prestados à comunidade; e, por fim, decidir se vale a pena continuar o projeto; ou se deve ser finalizado ou levado para outra comunidade.

Diante da crescente literatura em torno do tema e da necessidade de clarificar as experiências relacionadas à avaliação de projetos sociais, revelam-se pertinentes os estudos que, à luz do repertório teórico, discutem avanços e limites inerentes às diversas iniciativas vinculadas ao campo.

A partir desses apontamentos e considerando a relevância da avaliação de projetos sociais, este artigo tem como objetivo geral avaliar o Projeto Ser Criança "Educação pelo Brinquedo", implementado em Curvelo e Araçuaí, analisando os resultados por ele produzidos no sentido da formação social de crianças e adolescentes dele participantes. A cidade de Curvelo localiza-se no centro de Minas e Araçuaí, ao norte. Situam-se em duas regiões bastante fragilizadas do ponto de vista econômico e social. Daí a importância da superação desta realidade por projeto educacional inovador, complementar à escola pública. $\mathrm{O}$ referido projeto foi implementado pelo Centro Popular de Cultura e Desenvolvimento (CPCD), uma organização sem fins lucrativos do terceiro setor que tem por missão promover o desenvolvimento social e educacional de crianças e de adolescentes do ensino fundamental.

Têm-se como objetivos específicos: descrever as ações educativas inovadoras desenvolvidas com as crianças e adolescentes participantes; verificar a educação integral no programa de formação humana implementado pelos educadores sociais em termos de sua socialização e da promoção da cidadania; avaliar os resultados do Projeto Ser Criança em Curvelo, comparando-os com aqueles implementados em Araçuaí.

Adotou-se o método de avaliação de impacto, amplamente discutido por autores como Albuquerque (2006), Jannuzzi (2013), Marino (2003a) e Cohen \& Franco (2012) com foco nos resultados finais. Albuquerque (2006) foi tomado como referência estruturante para a realização da pesquisa.

A pesquisa pode ser classificada como descritiva, pois tem por base fontes bibliográficas, documentais e 25 entrevistas: com seis educadores, oito alunos, cinco pais dos alunos e seis egressos. Para avaliar o seu impacto, parte-se dos objetivos propostos pelo Projeto Ser Criança e seus resultados foram aferidos com base nas informações constantes dos relatórios técnicos elaborados pelos educadores e das entrevistas e nos resultados medidos pelo Índice de Desenvolvimento da Educação Básica (IDEB), aplicado em todo o território nacional pelo governo federal.

Este artigo apresenta relevância acadêmica na medida em que recupera aspectos centrais da literatura sobre o tema e discute uma experiência inovadora que gerou resultados positivos na formação de criança e adolescentes. Trata-se de uma avaliação de impacto que poderá suscitar o interesse de estudiosos e profissionais que atuam no terceiro setor e na gestão de projetos sociais, estimulando reflexões e a realização de novas pesquisas sobre o tema.

Do ponto de vista social, a pesquisa contribui para que as instituições do terceiro setor envolvidas possam verificar os efeitos sociais provocados nas comunidades onde seus respectivos projetos são desenvolvidos.

Diante da diversidade de encaminhamentos teóricos e metodológicos contemplado pela literatura sobre avaliação de projetos (Jannuzzi, 2014), este artigo de natureza teórico-empírica contribui para o avanço do debate, evidenciando os resultados 
gerados por um projeto social que possibilitou avanços na formação de um contingente de crianças e jovens, numa região economicamente fragilizada.
A próxima seção apresenta a fundamentação teórica que sustenta a abordagem proposta na pesquisa.

\section{REFERENCIAL TEÓRICO}

Considerando o objeto de estudo e a abordagem proposta, esta seção recupera aspectos centrais relacionadas à gestão e à avaliação de programas sociais. Essa composição revela-se necessária e suficiente para a fundamentação teórica do trabalho e para a análise dos dados obtidos na pesquisa.

\subsection{Gestão de Programas Sociais}

O desenvolvimento social e educacional constitui um objetivo fundamental das políticas sociais de cada país. Elas demandam um debate entre governo, sociedade civil, órgãos de cooperação internacional e participação dos grupos sociais e das pessoas interessadas na busca de meios que reduzam a desigualdade social e a pobreza. São necessários investimentos na formação de capital humano e social, que permitam a disponibilização de maiores recursos nas áreas de educação, saúde e nutrição porque são essenciais à vida humana, ao progresso e à sobrevivência coletiva (Kliksberg, 1998; Grayson \& Hodges, 2002).

O desenvolvimento social depende de ações governamentais que sejam pautadas pela eficiência e eficácia no uso dos recursos escassos e pela efetividade na promoção da cidadania (Sano \& Montenegro Filho, 2013). Contudo, as empresas privadas têm colaborado com projetos de responsabilidade social e de aprimoramento da cidadania, estimulando a criação de uma sociedade mais igualitária, por meio da educação corporativa, que busca formar o cidadão para empreender e criar coletivamente com recursos alternativos que proporcionam maior bem estar social à sociedade (Severo, 2014). Lutar pelo fim da miséria é um ponto importante a ser trabalhado nos países mais pobres. No combate à pobreza, criar redes sociais é uma boa alternativa para promover cooperação global entre as nações e a participação de cada pessoa na construção de um futuro melhor para a humanidade (Sachs, 2008).

Embora a Constituição Federal de 1988 preveja a educação para todos, o Brasil ainda precisa melhorar o acesso à creche e à pré-escola para alcançar inclusão de todas as crianças a partir de cinco anos de idade. A qualidade do ensino fundamental é, ainda, insatisfatória, não atingindo a alfabetização nos dois primeiros anos de ensino.
Além disto, tem-se constatado que alguns alunos chegam ao final do ensino fundamental ainda não bem alfabetizados. Nem todos os jovens conseguem concluir o ensino primário e cursar depois o ensino médio e profissionalizante que oferece poucas vagas no país. Torna-se necessária sua ampliação para se formar e qualificar um número maior de jovens para o mercado de trabalho (Giroletti, 2012).

$\mathrm{O}$ ensino superior no Brasil passa, igualmente, por um momento de transição e por certa crise de valores pela polarização apresentada: formar para o mercado ou para a cidadania. Nesse dilema, "o exercício da cidadania na vida pública torna-se um discurso opaco e vazio diante do apelo econômico" segundo Goergen (2014, p. 573). Não se pode reduzir, segundo este autor, a formação do individuo apenas à transmissão de ensinamentos instrumentais voltados ao mercado, deixando-se de lado a produção e a disseminação do conhecimento com o objetivo de formar pessoas e cidadãos para um novo mundo. A universidade continua, em grande medida, sendo a responsável por não deixar que o pensamento e a visão humanista não sejam esvaziados no mundo atual onde a economia tornase cada vez mais globalizada (Goergen, 2005).

A educação precisa evoluir junto com a sociedade por ser o principal fator responsável pelo seu crescimento. Por isto, a UNESCO propôs quatro pilares como parâmetros para a nova educação do Século XXI: "aprender a conhecer; aprender a fazer; aprender a viver juntos; e aprender a ser" (2012). Pelo "aprender a conhecer", as pessoas aprendem a entender o mundo em que vivem, a comunicar-se com os demais indivíduos e a buscar sua capacitação profissional. O conhecimento é importante para ajudar a suscitar a curiosidade intelectual, a estimular o senso crítico, a compreender a realidade atual e a aumentar a própria autonomia pela sua consciência e discernimento.

Pela perspectiva do "aprender a fazer", o indivíduo coloca em prática o aprendizado adquirido pelo aprender a conhecer e pela formação técnica e profissional que é necessária ao desempenho de toda profissão, ao trabalho em equipe, tendo iniciativa e gosto pelo risco.

Pelo "aprender a viver juntos ou aprender a viver com os outros", a UNESCO realça o desafio que todo sistema educacional deverá ter: enfrentar os conflitos étnicos, religiosos ou de ordem política ou econômica do mundo globalizado. A educação tem a função de ensinar a respeitar as diversidades culturais dos seres humanos, priorizando as semelhanças entre povos e a necessidade que se tem de conviver um com o outro e com respeito ao diferente. Esse convívio respeitoso poder ser ensinado nas escolas por meio da promoção de atividades esportivas, culturais e sociais.

Por fim, o "aprender a ser" refere-se à formação ética e à internalização de valores que cada 
pessoa deve receber para ser capaz de decidir sozinha, fazer críticas e ter seu próprio juízo de valor. A educação precisa levar as pessoas a desenvolver suas qualidades para o alcance de sua autonomia individual e de seus objetivos (UNESCO, 2012).

A educação integral deverá ser fruto da união de esforços do poder público e da sociedade que juntos podem contribuir para o acesso à cidadania, por meio da erradicação do analfabetismo. A educação integral pode ser entendida como um meio mais adequado para formar o cidadão pelo desenvolvimento de sua capacidade intelectual, física e social, usando-se todos os meios e recursos disponíveis na atualidade (Pio \& Czernisz, 2015).

\subsection{Avaliação de Programas Sociais}

Em face de sua relevância, a avaliação de projetos tem estimulado a realização de diversos estudos nas últimas décadas. No contexto internacional, há tempos, o assunto tem sido objeto de estudos consistentes como aquele realizado por Stufflebean (2001a como citado em Marino, 2003b, p. 50) que "realizou um extenso estudo analítico de 22 abordagens de avaliação baseados nos Standards de Avaliação de Programas elaborados pelo Joint Committee (1994)". Deve-se levar em conta que o referido estudo tomou como base diversos estudos, alguns deles produzidos na década de 1970, tais como Stake (1974) e Hasting (1976) com citado em Marino (2003b).

O exame da literatura revela diversos entendimentos em torno do significado da avaliação. Sem a pretensão de recuperar a extensa gama de definições, a seguir retomam-se algumas que contribuem para clarificar o conceito.

Conforme afirma Raposo (2001, p.93) “Avaliação é um processo crítico de identificação, monitoramento e aferição de situações, processos e resultados". Carvalho (2001, p.66) admite que avaliar é "atribuir valor, medir o grau de eficiência, eficácia e efetividade de políticas, programas e projetos sociais. Assim compreendida, a avaliação identifica processos e resultados, compara dados de desempenho, julga, informa e propõe".

Conforme explica Jannuzzi (2014)

Em uma definição mais pragmática e aplicada, proposta em Jannuzzi (2013a), avaliação refere-se ao conjunto de procedimentos técnicos para produzir informação e conhecimento, em perspectiva interdisciplinar, para desenho ex-ante, implementação e validação expost de programas e projetos sociais, por meio das diferentes abordagens metodológicas da pesquisa social, com a finalidade de garantir o cumprimento dos objetivos de programas e projetos (eficácia), seus impactos mais abrangentes em outras dimensões sociais, ou seja, para além dos públicos-alvo atendidos (efetividade) e a custos condizentes com a escala e complexidade da intervenção (eficiência). (Jannuzzi, 2014, p.26)

Para um projeto social ter sucesso, são necessários planejamento, monitoramento e avaliação. É importante avaliar os projetos sociais para verificar se os objetivos iniciais estão sendo executados e se as necessidades da comunidade local estão sendo atendidas. Para Jannuzzi (2014, p.26), a avaliação encerra

um levantamento consistente, sistemático e replicável de dados, informações e conhecimentos para aprimoramento da intervenção programática, versando sobre: as características essenciais do contexto de atuação; os públicos-alvo; o desenho; os arranjos de implementação; os custos de operação; os resultados de curto prazo; os impactos sociais e de mais longo prazo de um programa.

A avaliação de um projeto social pode ser feita no meio ou no final do projeto. Quando é feita no meio, permite que se acompanhe sua implementação e se tomem as decisões necessárias para seu término apropriado. Ao final, possibilita que se faça uma análise de resultados, comparandose a situação anterior com a posterior, o proposto com o realizado; um balanço dos meios utilizados e dos fins atingidos, objetivando avaliar seu impacto ou os resultados finais alcançados (Carvalho, 2003).

A denominada avaliação ex-post dos projetos sociais não é apenas útil para averiguar o desempenho das ações planejadas, mas, sobretudo, para determinar os caminhos futuros de continuidade ou não do projeto. As avaliações de impacto produzem melhores resultados quando feitas no longo prazo. Uma avaliação, realizada no curto prazo, pode omitir resultados importantes, que somente podem ser observados em períodos mais longos de implantação. Por isso, recomenda-se fazer avaliação ex-post dos projetos de longa duração ou que não tenham data para finalizar (Barros \& Lima, 2012).

A avaliação pode ser feita em projetos já finalizados ou em andamento. O objetivo de avaliar projetos sociais já finalizados é saber se eles merecem ser continuados ou não, mantendo-se o mesmo percurso ou introduzindo-se as mudanças que se fizerem necessários. Já a avaliação de projetos em andamento tem a finalidade de verificar se os resultados parciais estão dentro daquilo previsto, se deve continuar ou se necessárias alterações no projeto inicial para melhor adequá-lo à nova realidade da comunidade. Na avaliação ex-post dá- 
se ênfase a processos e ao impacto final alcançado. A avaliação de processo é o momento de verificar como estão a programação, a administração e o controle do projeto, para redefinir a aplicação de recursos financeiros (Cohen \& Franco, 2012).
A Figura 1 apresenta uma síntese dos pressupostos considerados pelos autores mencionados em relação ao processo de avaliação.

\begin{tabular}{|c|c|}
\hline AUTOR & PRESSUPOSTOS SOBRE AVALIAÇÃO \\
\hline Albuquerque (2006) & $\begin{array}{l}\text { envolve gestão por resultados e conflitos derivados das diferentes } \\
\text { racionalidades no processo de decisão, no plano e implementação dos projetos }\end{array}$ \\
\hline Carvalho (2001) & $\begin{array}{r}\text { pode ser vista como processo contínuo que embasa a tomada de decisão e } \\
\text { estimula o aprendizado }\end{array}$ \\
\hline Carvalho (2003) & $\begin{array}{r}\text { envolve o balanço dos meios e dos fins, objetivando avaliar o impacto ou } \\
\text { resultados alcançados }\end{array}$ \\
\hline Cohen \& Franco (2012) & $\begin{array}{r}\text { avaliação envolve certa racionalidade que se materializa na lógica de } \\
\text { realização das atividades e alocação de recursos }\end{array}$ \\
\hline Jannuzzi (2013) & $\begin{array}{r}\text { requer uma perspectiva interdisciplinar para desenho ex-ante, implementação } \\
\text { e validação ex-post }\end{array}$ \\
\hline Marino (2003b) & $\begin{array}{r}\text { aplicabilidade dos Standards de Avaliação de Programas definidos pelo The } \\
\text { Joint Committee of Standards for Education Evaluation. }\end{array}$ \\
\hline Raposo (2001) & $\begin{array}{r}\text { processo crítico de identificação, monitoramento e aferição de situações, } \\
\text { processos e resultados }\end{array}$ \\
\hline
\end{tabular}

Figura 1 - Avaliação de Projetos Sociais

Diante da inexistência de um modelo ideal e dos diversos entendimentos acerca da avaliação de projetos, na pesquisa realizada foram considerados pressupostos inerentes às diversas abordagens numa perspectiva de complementaridade. As contribuições de Albuquerque (2006), contudo, orientaram o arcabouço da pesquisa na medida em que o referido autor destaca a relevância da avaliação como método de gestão por resultados capaz de imprimir racionalidade ao processo de gestão de projetos sociais.

A próxima seção aborda os procedimentos metodológicos utilizados na realização da pesquisa.

\section{PROCEDIMENTOS METODOLÓGICOS}

A pesquisa realizada caracteriza-se como descritiva (Vergara, 1998) e envolveu a análise de dados quantitativos e qualitativos. Adotou-se o método de avaliação ex-post com foco nos impactos e resultados gerados pelo projeto com base em Albuquerque (2006).

A coleta de dados envolveu a análise de fontes documentais e a realização de entrevistas semiestruturadas. A coleta documental foi feita com base em fontes de dados primários e secundários. Os dados primários analisados foram extraídos dos 
relatórios técnicos elaborados pelas coordenadoras de cada Projeto com a participação de todos os educadores envolvidos. Nos relatórios descrevem-se as atividades educativas desenvolvidas mensalmente relacionadas ao cumprimento dos objetivos escritos do Projeto. Foram usados dados secundários provenientes de vídeos, fotos, reportagens, entrevistas existentes nos arquivos do CPCD ou disponíveis na internet no site da própria instituição. Outra fonte importante foram os dados de avaliação da educação básica feita pelo IDEB e disponibilizados aos interessados pelo Instituto Nacional de Estudos e Pesquisas Educacionais Anísio Teixeira - INEP.

A coleta de dados envolveu a realização de 25 entrevistas semiestruturadas com educadoras, egressos, alunos e seus pais envolvidos no Projeto em Curvelo e Araçuaí. A escolha dos entrevistados justifica-se pela relevância de sua participação no Projeto nas duas cidades. Em Curvelo, foram entrevistadas seis pessoas: três educadoras e três egressos. A primeira egressa do Projeto era, à época, responsável pelo setor de vendas de uma Cooperativa em Curvelo. A segunda egressa era, à época da pesquisa, educadora social atuando em Raposos, região metropolitana de Belo Horizonte. Por fim, o terceiro egresso tornou-se empresário, dono de uma marcenaria na cidade que emprega outros ex-alunos do Projeto. Foram feitas somente seis entrevistas em Curvelo porque o Projeto foi desativado quando a Cúria episcopal resolveu suspender o contrato de comodato do terreno onde ele funcionava. Em Araçuaí, foram entrevistadas 19 pessoas. As primeiras foram feitas com as três educadoras responsáveis por cada um dos grupos de crianças pertencentes ao Projeto. Três entrevistas foram realizadas com egressos do Projeto: o primeiro egresso era, a época, professor de música em uma Universidade de Música Popular em Barbacena; o segundo era educador social no Projeto quando a pesquisa foi realizada; a terceira era, à época, assistente de produção de um Grupo de Teatro em Barbacena, que realizava apresentações musicais e teatrais em várias cidades brasileiras e no exterior. O terceiro grupo de entrevistados foi formado por oito alunos do Projeto à época. Finalmente, o último grupo de entrevistados foi constituído por cinco pais de alunos que participavam do Projeto quando da realização da pesquisa.

As entrevistas semiestruturadas foram realizadas com base em quatro roteiros, para melhor avaliar os resultados produzidos pelos dois Projetos. $\mathrm{O}$ primeiro roteiro foi aplicado às educadoras do Projeto, o segundo, aos egressos do Projeto, o terceiro, aos alunos e o quarto aos pais dos alunos. As perguntas foram divididas em três blocos, com cinco perguntas cada um. No primeiro bloco, as perguntas focalizam as ações educativas inovadoras utilizadas no dia a dia do Projeto para ensinar as crianças e adolescentes. No segundo bloco, as perguntas estão direcionadas a medir a educação integral como forma de ensinar usando a mente, o corpo e a vida social, através de atividades culturais e esportivas. O terceiro roteiro foi reservado às questões de formação social visando aproveitar a socialização das crianças e adolescentes e o desenvolvimento da cidadania plena.

Para atingir o objetivo da pesquisa tomouse como referência os pressupostos do método de gestão por resultados, considerados por Albuquerque (2006). Segundo o referido autor, a avaliação imprime racionalidade ao processo e possibilita a mensuração dos resultados e dos impactos gerados.

$\mathrm{Na}$ avaliação do Projeto Ser Criança como um projeto educacional inovador toma-se por base as notas dos alunos das escolas públicas. Em função da indisponibilidade de dados, fez-se o recorte das notas obtidas nos anos de 2005 a 2013. De posse delas, comparam-se a nota média alcançada pelos alunos dos dois municípios pelo IDEB com os escores a serem atingidos a partir de 2007 nos dois municípios. Em segundo lugar, para avaliar o impacto do Projeto Ser Criança na formação dos seus alunos será feito um comparativo das notas dos alunos atingidas no IDEB, dividindo-se os resultados em dois grupos. De um lado, as notas obtidas pelos participantes do Projeto; de outro, as notas dos alunos das escolas da rede de ensino público que dele não participam.

Assim, em Curvelo, serão comparados, de um lado, os dados das escolas parceiras do Projeto Escola Municipal Dr. Viriato Diniz Mascarenhas, Escola Municipal Antonino Diniz Couto, Escola Estadual Ministro Adauto Lucio Cardoso, Escola Estadual Interventor Alcides Lins - localizadas em bairros próximos ao Projeto; de outro, com os rendimentos das escolas não parceiras que foram escolhidas pelo critério de proximidade geográfica: Escola Municipal Filomena de Oliveira Leite e Escola Estadual São Vicente de Paulo.

E, por fim, o mesmo comparativo será feito com os alunos de Araçuaí, tomando-se por base os resultados do IDEB. Serão analisados os resultados obtidos pelas escolas parceiras do Projeto, que estão localizadas no mesmo bairro ou em bairros vizinhos, onde estuda a maioria dos alunos do Projeto, a saber: a Escola Estadual Dom José de Haas, a Escola Estadual Professor Leopoldo Pereira e a Escola Estadual Manoel Fulgêncio. Seus resultados serão comparados às notas dos alunos das escolas não parceiras - a Escola Estadual Isaltina Cajubi Fulgêncio e a Escola Estadual Frei Rogato localizadas em bairros vizinhos ao Projeto. 


\section{ANÁlISE E DISCUSSÃO DOS RESULTADOS}

O CPCD foi fundado em 1984, na cidade de Belo Horizonte, pelo antropólogo e educador, Tião Rocha, com o objetivo de atuar nas áreas de educação popular de qualidade e desenvolvimento comunitário sustentável, tendo a cultura como matéria prima e instrumento de trabalho pedagógico e institucional. O CPCD é uma entidade do terceiro setor classificada como uma ONG, sem fins lucrativos, de utilidade pública federal, estadual e municipal. Sua missão é realizar projetos inovadores, programas integrados e plataformas de transformação social e desenvolvimento sustentável, destinados, preferencialmente, às comunidades de cidades pequenas com menos de 50 mil habitantes.

O CPCD mantém os Projetos com recursos financeiros recebidos dos setores público e privado. Nesses vários anos de existência, o Projeto foi financiado com recursos procedentes de fundações estrangeiras como a Fundação Kellogg; dos governos federal, estadual e municipal; das seguintes empresas brasileiras: Natura, Petrobras, Vale do Rio Doce, Unibanco, Fundação Itaú Social, Colégio Nazareth de Araçuaí, Criança Esperança e Unesco. As despesas com a manutenção do Projeto em Curvelo giraram em torno de duzentos mil reais por ano para custear os salários de dez funcionários contratados e as demais despesas com infraestrutura e serviços. Em Araçuaí, o investimento foi menor ao redor de cento e cinquenta mil reais por ano, destinado ao pagamento de salários de nove funcionários e das demais despesas com serviços e infraestrutura.

\subsection{Projeto Ser Criança: contextualização.}

O Projeto Ser Criança "Educação pelo brinquedo" foi criado pelo CPCD para atender crianças e adolescentes de 7 a 14 anos, matriculados na rede de ensino público. Destina-se ao atendimento de alunos provenientes de comunidades classificadas como sendo de risco social. Eles devem frequentar atividades do Projeto no turno inverso ao seu horário de aula na escola pública onde devem estar devidamente matriculados. As atividades pedagógicas do Projeto devem ser consideradas como complementares ao ensino fundamental recebido na escola pública. O Projeto visa promover educação integral, utilizando novos recursos pedagógicos como os ligados ao brinquedo e ao brincar.

O Projeto conquistou o $1^{\circ}$ lugar no Concurso Prêmio Itaú-Unicef "Educação \& Participação". O referido concurso, de âmbito nacional, foi realizado no ano de 1995 e envolveu 406 projetos, tendo como finalidade identificar "a melhor contribuição de uma organização não governamental $(\mathrm{ONG})$ para a melhoria e qualidade da escola pública brasileira". O Projeto promove atividade complementar à vida escolar, visando garantir a educação integral para as crianças e os adolescentes em situação de risco social, a partir do brinquedo e do brincar, atuando nas áreas de educação popular e desenvolvimento comunitário, tendo a cultura como matéria prima e instrumento de trabalho pedagógico e institucional.

Com as dificuldades sócio-econômicas enfrentadas pelas cidades da região central e norte de Minas na falta de oportunidades de trabalho, de renda e de acesso a educação, percebe-se a importância da existência de projetos sociais de qualidade que promovam o desenvolvimento social, e criem oportunidades para reduzir a desigualdade social. Araçuaí tem uma economia pouco desenvolvida, sendo a extração mineral a responsável pela geração de renda e empregos, na sua maioria, informais, dificultando o crescimento da região, sendo necessária a criação de ações voltadas para aumentar a geração de bens e serviços. Em Curvelo, os trabalhos formais são ofertados pela indústria têxtil, setor de comércio e serviços, que necessitam de ações voltadas para melhorar a distribuição de renda no município, por meio de parcerias entre o setor privado, público e terceiro setor.

O Projeto fundamentou-se no trinômio conceitual: novo educador, novo educando, nova prática educativa, a partir de ações pedagógicas inovadores, prazerosas e de aprendizagem permanente. Foram desenvolvidos cinco objetivos específicos, descritos na Figura 2, que seguem a proposta da educação integral de propiciar o ensino por várias dimensões, abordando a mente, o corpo e a vida social, como um meio mais adequado de formar o indivíduo e o cidadão. 


\section{OBJETIVOS ESPECÍFICOS DO PROJETO SER CRIANÇA}

1 - Privilegiar o "diálogo" como mediador de "relações iguais entre pessoas diferentes", envolvendo educadores, pais, alunos e comunidade;

2 - Priorizar o respeito às diferenças individuais, valorizando os saberes, os fazeres e os ritmos de aprendizagem de cada um;

3 - Utilizar todas as situações - rotineiras e ocasionais - vividas pelas crianças e jovens participantes em suas comunidades como "conteúdos educacionais" programáticos e significativos;

4 - Transformar todos os espaços comunitários ocupados pelos participantes em "espaços de aprendizagem", e todas as "escolas" em "centros de cultura comunitária";

5 - Designar como "educadores" todas as pessoas (professores, funcionários, pais, alunos, etc, independente da idade, sexo e função) participantes do processo educativo.

Figura 2 - Quadro objetivos específicos do Projeto Ser Criança

Fonte: Dados da Pesquisa, (2017).

O Projeto envolveu as seguintes pedagogias: Pedagogia da Roda, Pedagogia do Brinquedo, Pedagogia do Sabão, Pedagogia do Abraço e Pedagogia do Copo Cheio. A Pedagogia da Roda permite o diálogo entre os educadores e educandos, por meio do qual todos ensinam e aprendem a partir das experiências de vida.

A Pedagogia do Brinquedo procura estimular o aprendizado de forma espontânea em um ambiente informal, respeitando o tempo e o ritmo da criança. $\mathrm{O}$ aprendizado baseia-se em brincadeiras que estimulam a socialização, a troca de experiências e o companheirismo.

A Pedagogia do Sabão é o resultado do aprender fazendo por meio da realidade da comunidade, que possui suas práticas tradicionais e culturais, que podem gerar desenvolvimento sustentável e econômico, por meio da educação integral, que une as crianças e as mães no processo educacional.
A Pedagogia do Abraço tem a função de despertar o espírito solidário e afetivo, descartando a ideologia do autodesprezo, fortalecendo a autoestima, permitindo uma melhor integração do grupo e facilitando o processo de aprendizagem.

A Pedagogia do Copo Cheio trabalha a partir do índice de potencial de desenvolvimento humano (IPDH), que mede a capacidade de acolhimento, de convivência, de aprendizagem e de oportunidade.

As ações do Projeto estão apoiadas no tripé: metodologia inovadora, capacitação de educadores e envolvimento comunitário. A metodologia inovadora teve início a partir da concepção de educação como algo que só ocorre no plural e de que todos nós somos educadores e educandos. Para conseguir êxitos nessa metodologia, foram criadas algumas ações metodológicas conforme descrito na Figura 3.

\section{AÇÕES METODOLÓGICAS}

A busca sistemática de formas criativas e inovadoras de estímulo à participação (a roda, os jogos, as atividades lúdicas);

A valorização dos saberes e fazeres (a cultura da criança e da comunidade como matéria prima a ser lida, escrita, pintada, dançada, encenada, etc.) pelos projetos e pela escola;

O diálogo como princípio gerador de uma prática educativa plural e norteador de relações mais humanas e mais iguais entre professores e alunos.

Figura 3 - Quadro ações metodológicas

Fonte: Dados da Pesquisa, (2017).

Conforme Cohen e Franco (2012) cada projeto envolve certa racionalidade que influencia sua concepção e implementação. No caso do projeto em tela, os conteúdos metodológico e pedagógico assumem papel central, como se pode notar nos apontamentos anteriores.
Em complemento às dificuldades que o Estado vem enfrentando para cumprir seus objetivos no campo educacional e social, como a escassez de recursos e as complexas demandas, tem crescido os projetos sociais desenvolvidos por organizações do terceiro setor, com ações voltadas para a comunidade como forma de diminuir a desigualdade educacional 
e social. O Governo e as empresas privadas são os principais provedores de recursos para o terceiro setor. Têm-se como premissa da pesquisa: o Projeto Ser Criança promove ações educativas que permite as crianças e adolescentes uma melhor inserção social e educacional na sociedade por meio das técnicas utilizadas na educação integral.

\subsection{Os Resultados do Projeto em Curvelo}

Antes de definir as atividades que serão trabalhadas no Projeto, é sempre feito um diagnóstico das dificuldades de aprendizagem dos alunos, para depois pensar na melhor forma inovadora e criativa que possibilitaria um melhor aprendizado. Do início do Projeto em 1989 até o final em 2012 foram atendidos aproximadamente cinco mil alunos, numa média de cerca de 200 alunos por ano.

O primeiro jogo educativo surgiu da percepção da grande defasagem na aprendizagem da matemática. No afã de melhorá-la, foi identificada uma criança de onze anos que estava repetindo a primeira série do ensino fundamental pela quarta vez porque não conseguia aprender as suas quatro operações básicas: o somar, o subtrair, o multiplicar e o dividir. Os educadores do Projeto perceberam que essa criança era muito boa no jogo de dama. Ela ganhava sempre as partidas de dama de seus colegas. Constatada esta expertise, tiveram, então, a ideia de criar a "damática". No tabuleiro de dama, são espalhados os números aleatoriamente, como o jogo é feito com tampinhas de garrafas de refrigerantes, coloca-se um sinal de mais (+), ou de menos (-), ou de multiplicar (x), em cima de cada tampinha, e, a cada jogada, o jogador deve fazer primeiro a conta e depois mexer as tampinhas. Caso o jogador erre a conta, o outro jogador deve fazê-la. Com pouco tempo, a criança conseguiu aprender as operações básicas da matemática, surpreendendo sua professora quando entregou um dever de casa com todas as contas resolvidas. A partir da ideia da damática, foram desenvolvidos outros 168 jogos.

Para analisar o impacto quantitativo do Projeto Ser Criança no melhor desempenho dos alunos de Curvelo, foram utilizados os resultados do IDEB divulgados pelo INEP. Por ele, faz-se uma avaliação nacional do ensino fundamental ao final da primeira etapa, por meio da aplicação da Prova Brasil para os alunos da $4^{\mathrm{a}}$ série / $5^{\circ}$ ano; e, ao final da segunda etapa, aos alunos da $8^{\mathrm{a}}$ série $/ 9^{\circ}$ ano. Concluídos os trabalhos, o IDEB apresenta, em conjunto, a taxa de aprovação em cada uma das séries.

Em Curvelo, os resultados na avaliação do IDEB para a $4^{\mathrm{a}}$ série / $5^{\circ}$ ano descritos na Tabela 1 , demonstra que no ano 2013 as escolas parceiras do Projeto - Escola Municipal Dr. Viriato Diniz Mascarenhas obteve 6,4, já a Escola Municipal Antônio Diniz Couto 6,0, sendo maiores que a média projetada de 5,0 para as escolas do município, e também maior que a nota da escola não parceira Escola Municipal Filomena de Oliveira Leite que obteve 3,8 .

Tabela 1 - IDEB Escolas Públicas de Curvelo: $4^{\mathrm{a}}$ série / $5^{\circ}$ ano

\begin{tabular}{c|c|c|c|c|c}
\hline \multicolumn{7}{c}{ Município } & \multicolumn{3}{c}{ Escola Municipal } \\
\hline \multirow{2}{*}{ Ano } & $\begin{array}{c}\text { Média } \\
\text { Projetada }\end{array}$ & $\begin{array}{c}\text { Média } \\
\text { Verificada }\end{array}$ & $\begin{array}{c}\text { Dr. Viriato Diniz } \\
\text { Mascarenhas }\end{array}$ & $\begin{array}{c}\text { Antônio Diniz } \\
\text { Couto }\end{array}$ & $\begin{array}{c}\text { Filomena de } \\
\text { Oliveira Leite }\end{array}$ \\
\hline 2005 & - & 3,9 & 4,1 & 4,2 & 3,8 \\
2007 & 4,0 & 4,6 & 4,3 & 4,6 & 4,4 \\
2009 & 4,4 & 5,2 & 5,4 & 5,0 & 5.3 \\
2011 & 4,8 & 5,9 & 5,9 & 6,0 & 5,3 \\
2013 & 5,0 & 6,2 & 6,4 & 6,0 & 3,8 \\
\hline
\end{tabular}

Fonte: INEP - Instituto Nacional de Estudos e Pesquisas Educacionais Anísio Teixeira (2015) disponível em http://ideb.inep.gov.br/resultado/home.seam?cid=217621 recuperado em 15 de março de 2015

De acordo com a Tabela 2, os resultados da $8^{\mathrm{a}}$ serie $/ 9^{\circ}$ ano também foram melhores nas escolas parceiras, Escola Estadual Interventor Alcides Lins que obteve 5,0, já a Escola Estadual Ministro Adauto Lúcio Cardoso alcançou 4,4, em comparação com a média projetada de 4,1 para o município e com a nota de 3,1 da escola não parceira Escola Estadual São
Vicente de Paulo. O Projeto tem desenvolvido ações que permitem a educação integral das crianças e adolescentes, levando as crianças para o cinema, para roda de batuque, para rua de lazer e recebendo visitantes de outros países, estados e cidades. 
Tabela 2 - IDEB Escolas Públicas de Curvelo: $8^{a}$ série $/ 9^{\circ}$ ano

\begin{tabular}{|c|c|c|c|c|c|}
\hline \multicolumn{3}{c|}{ Município } & \multicolumn{3}{c}{ Escola Estadual } \\
\hline Ano & $\begin{array}{c}\text { Média } \\
\text { Projetada }\end{array}$ & $\begin{array}{c}\text { Média } \\
\text { Verificada }\end{array}$ & $\begin{array}{c}\text { Interventor } \\
\text { Alcides Lins }\end{array}$ & $\begin{array}{c}\text { Ministro } \\
\text { Adauto Lúcio } \\
\text { Cardoso }\end{array}$ & $\begin{array}{c}\text { São Vicente } \\
\text { de Paulo }\end{array}$ \\
\hline 2005 & - & 3,2 & 2,7 & 2,2 & 2,7 \\
2007 & 3,2 & 3,7 & 4,2 & 2,9 & 2,8 \\
2009 & 3,4 & 3,9 & 4,2 & 3,8 & 3,1 \\
2011 & 3,7 & 4,4 & 4,4 & 4,2 & 3,0 \\
2013 & 4,1 & 4,8 & 5,0 & 4,4 & 3,1 \\
\hline
\end{tabular}

Fonte: INEP (2015) disponível em http://ideb.inep.gov.br/resultado/home.seam?cid=217621 recuperado em 15 de março de 2015

As taxas de aprovação em 2013 na $4^{\text {a }}$ série / $5^{\circ}$ ano descritas na Tabela 3 referente as escolas parceiras do Projeto: Escola Municipal Dr. Viriato Diniz Mascarenhas foi de 97,5, já na Escola
Municipal Antônio Diniz Couto foi de 95,3, sendo superior ao escore alcançado pela escola não parceira, Escola Municipal Filomena de Oliveira Leite que obteve 93,5 .

Tabela 3 - Taxa de aprovação nas Escolas Públicas de Curvelo: $4^{\mathrm{a}}$ série / $5^{\mathrm{o}}$ ano

\begin{tabular}{l|c|c|c|c}
\hline \multirow{2}{*}{ Ano } & Taxa Média de & \multicolumn{3}{|c}{ Escola Municipal } \\
\cline { 3 - 5 } & $\begin{array}{c}\text { Aprovação no } \\
\text { Município }\end{array}$ & $\begin{array}{c}\text { Dr. Viriato Diniz } \\
\text { Mascarenhas }\end{array}$ & $\begin{array}{c}\text { Antônio Diniz } \\
\text { Couto }\end{array}$ & $\begin{array}{c}\text { Filomena de } \\
\text { Oliveira Leite }\end{array}$ \\
\hline 2005 & 92,2 & 80,5 & 88,8 & 87,5 \\
2007 & 91,6 & 82,4 & 90,9 & 91,0 \\
2009 & 98,8 & 86,7 & 87,5 & 96,4 \\
2011 & 99,5 & 92,9 & 96,4 & 90,4 \\
2013 & 99,8 & 97,5 & 95,3 & 93,5 \\
\hline
\end{tabular}

Fonte: INEP (2015) disponível em http://ideb.inep.gov.br/resultado/home.seam?cid=217621 recuperado em 15 de março de 2015

$\mathrm{Na} 8^{\mathrm{a}}$ série $/ 9^{\circ}$ ano os resultados descritos na Tabela 4 pelas duas escolas parceiras: Escola Estadual Interventor Alcides Lins foi de 87,8, Escola Estadual Ministro Adauto Lúcio Cardoso foi de 86,3, sendo superior ao escore da escola não parceira, Escola Estadual São Vicente de Paulo que alcançou
70,2. O envolvimento com as escolas parceiras trocando informações sobre as dificuldades de cada criança permite que as educadoras do Projeto façam a intervenção individualizada no ensino de cada aluno, trabalhando os pontos fracos de cada um na busca de melhorar o seu aprendizado.

Tabela 4 - Taxa de aprovação nas Escolas Públicas de Curvelo: $8^{\mathrm{a}}$ série / $9^{\circ}$ ano

\begin{tabular}{c|c|c|c|c}
\hline \multirow{2}{*}{ Ano } & \multirow{2}{*}{$\begin{array}{c}\text { Taxa Média de } \\
\text { Aprovação no } \\
\text { Município }\end{array}$} & $\begin{array}{c}\text { Escola Estadual } \\
\text { Interventor } \\
\text { Alcides Lins }\end{array}$ & $\begin{array}{c}\text { Ministro } \\
\text { Adauto Lúcio } \\
\text { Cardoso }\end{array}$ & $\begin{array}{c}\text { São Vicente de } \\
\text { Paulo }\end{array}$ \\
\hline 2005 & 67,9 & 59,8 & 48,7 & 57,0 \\
2007 & 76,0 & 84,5 & 64,1 & 69,2 \\
2009 & 77,5 & 79,3 & 89,6 & 72,0 \\
2011 & 84,7 & 79,6 & 89,6 & 72,0 \\
2013 & 89,2 & 87,8 & 86,3 & 70,2 \\
\hline
\end{tabular}

Fonte: INEP (2015) disponível em http://ideb.inep.gov.br/resultado/home.seam?cid=217621 recuperado em 15 de março de 2015 
Quanto à avaliação de matemática na prova Brasil em 2013 da $4^{\mathrm{a}}$ série / $5^{\circ}$ ano descritas na Tabela 5, as notas das escolas parceiras: Escola Municipal Dr. Viriato Diniz Mascarenhas foi
237,68, já a Escola Municipal Antônio Diniz Couto obteve 229,24, superando a média do município de 211,99 e da escola não parceira: Escola Municipal Filomena de Oliveira Leite que alcançou 215,51.

Tabela 5 - Nota de Matemática na Prova Brasil nas Escolas Públicas de Curvelo: $4^{\mathrm{a}}$ série / $5^{\circ}$ $5^{\circ}$ ano

\begin{tabular}{c|c|c|c|c}
\hline \multirow{2}{*}{ Ano } & \multirow{2}{*}{$\begin{array}{c}\text { Média na Nota } \\
\text { de Matemática }\end{array}$} & \multicolumn{3}{|c}{ Escola Municipal } \\
\cline { 3 - 5 } & no Município & $\begin{array}{c}\text { Dr. Viriato Diniz } \\
\text { Mascarenhas }\end{array}$ & $\begin{array}{c}\text { Antônio Diniz } \\
\text { Couto }\end{array}$ & $\begin{array}{c}\text { Filomena de } \\
\text { Oliveira Leite }\end{array}$ \\
\hline 2005 & 181,40 & 193,97 & 185,84 & 169,87 \\
2007 & 181,34 & 203,81 & 199,86 & 189,87 \\
2009 & 208,43 & 232,01 & 218,37 & 191,85 \\
2011 & 205,86 & 230,42 & 238,14 & 218,29 \\
2013 & 211,99 & 237,68 & 229,24 & 215,51 \\
\hline
\end{tabular}

Fonte: INEP (2015) disponível em http://ideb.inep.gov.br/resultado/home.seam?cid=217621 recuperado em 15 de março de 2015

$\mathrm{Na} 8^{\mathrm{a}}$ série $/ 9^{\circ}$ ano o escore obtido pelas escolas parceiras: Escola Estadual Interventor Alcides Lins foi de 271,62, a Escola Estadual Ministro Adauto Lúcio Cardoso foi de 256,06 superando a escola não parceira, Escola Estadual São Vicente de Paulo que obteve 231,10 (Tabela 6). Isto demonstra que as intervenções pedagógicas feitas pelas educadoras do Projeto em conjunto auxiliam na melhoria da aprendizagem medida pelos bons resultados dos alunos das escolas parceiras, registrados pelo IDEB.

Tabela 6 - Nota de Matemática na Prova Brasil nas Escolas Públicas de Curvelo: $8^{\text {a }}$ série / $9^{\circ}$ ano

\begin{tabular}{l|c|c|c|c}
\hline \multirow{2}{*}{ Ano } & \multirow{2}{*}{$\begin{array}{c}\text { Média na Nota } \\
\text { de Matemática } \\
\text { no Município }\end{array}$} & $\begin{array}{c}\text { Escola Estadual } \\
\text { Alcides Lins }\end{array}$ & $\begin{array}{c}\text { Ministro } \\
\text { Adauto Lúcio } \\
\text { Cardoso }\end{array}$ & $\begin{array}{c}\text { São Vicente de } \\
\text { Paulo }\end{array}$ \\
\hline 2005 & 249,10 & 247,45 & 247,09 & 252,27 \\
2007 & 248,60 & 252,27 & 236,31 & 226,53 \\
2009 & 251,47 & 260,65 & 236,59 & 231,63 \\
2011 & 255,98 & 264,28 & 234,64 & 230,16 \\
2013 & 261,84 & 271,62 & 256,06 & 231,10 \\
\hline
\end{tabular}

Fonte: INEP (2015) disponível em http://ideb.inep.gov.br/resultado/home.seam?cid=217621 recuperado em 15 de março de 2015

Os alunos das escolas parceiras do Projeto na avaliação ocorrida em 2013 tiveram um melhor desempenho em língua portuguesa no âmbito da $4^{\mathrm{a}}$ série / $5^{\circ}$ ano: a Escola Municipal Dr. Viriato Diniz Mascarenhas obteve 222,94, a Escola Municipal Antônio Diniz Couto 212,93. A média obtida por eles foi superior à media das notas dos alunos do mesmo nível no município $(197,30)$ e da escola não parceira: Escola Municipal Filomena de Oliveira Leite que foi de 203,33 (Tabela 7). Isto porque nos encontros diários do Projeto são desenvolvidas atividades que estimulam o aprendizado em língua portuguesa, como, por exemplo, o trabalho com livros que acontecem com frequência, seja na biblioteca, debaixo de uma árvore ou em qualquer outro lugar. 
Tabela 7 - Nota de Língua Portuguesa na Prova Brasil nas Escolas Públicas de Curvelo: $4^{\mathrm{a}}$ série $/ 5^{\circ}$ ano

\begin{tabular}{|c|c|c|c|c|}
\hline \multirow[b]{2}{*}{ Ano } & \multirow{2}{*}{$\begin{array}{l}\text { Média na Nota de } \\
\text { Língua Portuguesa } \\
\text { no Município }\end{array}$} & \multicolumn{3}{|c|}{ Escola Municipal } \\
\hline & & $\begin{array}{l}\text { Dr. Viriato Diniz } \\
\text { Mascarenhas }\end{array}$ & $\begin{array}{c}\text { Antônio Diniz } \\
\text { Couto }\end{array}$ & $\begin{array}{l}\text { Filomena de } \\
\text { Oliveira Leite }\end{array}$ \\
\hline 2005 & 176,00 & 191,62 & 177,71 & 167,88 \\
\hline 2007 & 167,04 & 186,45 & 182,87 & 175,92 \\
\hline 2009 & 187,55 & 207,08 & 199,53 & 186,26 \\
\hline 2011 & 190,43 & 216,02 & 208,17 & 206,79 \\
\hline 2013 & 197,30 & 222,94 & 212,93 & 203,33 \\
\hline
\end{tabular}

Fonte: INEP (2015) disponível em http://ideb.inep.gov.br/resultado/home.seam?cid=217621 recuperado em 15 de março de 2015

Da mesma forma, o melhor desempenho em língua portuguesa dos alunos da escola parceira, Interventor Alcides tirando a nota de 271,79, na prova Brasil da $8^{a}$ série $/ 9^{\circ}$ ano deve ser atribuído, em grande parte, ao trabalho efetuado pelo Projeto na cidade de Curvelo desde o ano 1989 com seus alunos e de outras escolas parceiras em comparação com a média do município que foi de 258,42 (Tabela 8). Na busca pelo aprimoramento dos conhecimentos em língua portuguesa, os adolescentes são levados para as praças onde acontecem as rodas do contar histórias, que aguçam neles a vontade de leitura.

Tabela 8- Nota de Língua Portuguesa na Prova Brasil nas Escolas Públicas de Curvelo: $8^{\text {a }}$ série $/ 9^{\circ}$ ano

\begin{tabular}{|c|c|c|c|c|}
\hline \multirow[t]{2}{*}{ Ano } & \multirow[b]{2}{*}{$\begin{array}{c}\text { Média na Nota de } \\
\text { Língua Portuguesa } \\
\text { no Município }\end{array}$} & \multicolumn{3}{|c|}{ Escola Estadual } \\
\hline & & $\begin{array}{l}\text { Interventor } \\
\text { Alcides Lins }\end{array}$ & $\begin{array}{c}\text { Ministro } \\
\text { Adauto Lúcio } \\
\text { Cardoso }\end{array}$ & $\begin{array}{c}\text { São Vicente de } \\
\text { Paulo }\end{array}$ \\
\hline 2005 & 238,10 & 228,05 & 230,39 & 234,68 \\
\hline 2007 & 245,51 & 246,60 & 244,21 & 220,55 \\
\hline 2009 & 252,68 & 261,05 & 250,19 & 224,48 \\
\hline 2011 & 254,18 & 264,02 & 243,65 & 222,56 \\
\hline 2013 & 258,42 & 271,79 & 248,37 & 238,36 \\
\hline
\end{tabular}

Fonte: INEP (2015) disponível em http://ideb.inep.gov.br/resultado/home.seam?cid=217621 recuperado em 15 de março de 2015

Os bons resultados na aprendizagem da matemática e da língua portuguesa permitem concluir que os impactos educacionais proporcionados pelo Projeto podem ser comprovados pelo melhor desempenho dos alunos das escolas parceiras quando comparados com o rendimento dos alunos das escolas públicas não participantes. Com base nesses resultados diferenciados impõe-se uma conclusão: propor o recomeço do Projeto Ser Criança em Curvelo ou implantá-lo em outro espaço com maior abertura e sensibilidade à transformação social e das pessoas pela educação, a começar pelas crianças e pelos adolescentes, protagonistas do futuro do país. As metodologias de ensino e aprendizagem, utilizadas pela equipe de educadores do CPCD cuja eficiência já foi comprovada na prática, poderão fazer maravilhas em outros municípios mineiros e brasileiros.

\subsection{Avaliação do Projeto em Araçuaí}

Da mesma forma ao realizado em Curvelo, o Projeto procurou desenvolver ações educativas e de formação humana, buscando fazer uma interferência positiva e modificadora na vida das crianças e adolescentes, ensinando a respeitar as diferenças de cada individuo, pois cada um tem seu ritmo, seu fazer e seu saber. Do início do Projeto em 1998 até o ano de 2014 foram atendidos aproximadamente três mil alunos numa média anual de cerca de 180 participantes.

Novamente, os quatro pilares da educação da UNESCO foram associados às ações pedagógicas desenvolvidas pelo CPCD no Projeto. Assim, o “aprender a conhecer” está associado à Pedagogia da Roda que ensina os alunos a falar em público, a resolver os problemas por meio do diálogo, a ser mais crítico e aprender com a experiência de vida do outro. São perceptíveis os resultados alcançados pelo emprego da Pedagogia da Roda expressos no 
depoimento da aluna Jaqueline de 14 anos: "A roda é nossa maior oportunidade de crescimento dentro do Projeto. Nela, aprendemos a interagir uns com os outros; aprendemos a ouvir, a falar o que sentimos. Todos têm oportunidade de expressar seus sentimentos".

O “aprender a fazer” está associado a várias atividades. Destaca-se a Pedagogia do Sabão que permite o desenvolvimento da capacidade de trabalhar em equipe, a formação social e a autosustentabilidade; ensinando na prática a seguir cada etapa na preparação da receita, conforme experiência descrita pela aluna Leila de 13 anos: "Foi legal porque, a cada etapa da receita, parecia que era uma coisa diferente: o sabão ralado parecia coco, no fogo parecia doce de mamão e o resultado foi uma pasta de brilho. Gostei muito da ideia e a gente fez brincando".

O "aprender a viver juntos" está associado à Pedagogia do Abraço que desenvolve o espírito solidário e afetivo entre os membros do grupo, rompendo com a ideologia do autodesprezo que contamina e subjuga crianças e adolescentes. A Pedagogia do Abraço tem como premissa o investimento na afetividade, com abraços, beijos, palavras carinhosas, gestos solidários e cafuné, na busca da dignidade humana e da cidadania. Para desenvolver essa pedagogia são utilizadas a dinâmica do Amigo carinhoso e a Dinâmica do Amor, pois levam as crianças a perceberem o quanto é fundamental receber um abraço, um aperto de mão e palavras amigas.

$\mathrm{O}$ "aprender a ser" pode estar associado à Pedagogia do Brinquedo, porque aprender e ensinar brincando traz em si toda a riqueza de possibilidades de relacionamento e companheirismo, socialização e troca de experiências, conhecimento do outro e respeito às diferenças, aos desejos e às visões diferenciadas de mundo. Tais atitudes são elementos essenciais para construção de uma relação plural entre educadores e educandos, condição básica para existência de uma prática educativa de qualidade e para a descoberta e apropriação do saber e do fazer.

Outra forma criativa usada no Projeto é o chamado Biscoito Escrevido. Esse procedimento pedagógico tem sido usado para alcançar bons resultados e como forma de ensinar, prazerosa e eficaz. Pela receita de elaboração de uma rodada de biscoito de polvilho, são ensinadas as quatro operações matemáticas, pela separação, contagem e pesagem dos ingredientes. Depois de separá-los e agrupá-los, é o momento de colocar a mão na massa. E quando a massa está pronta, cada aluno escreve com ela o seu nome, desenha objetos, números e outras letras e palavras que estão sendo ensinados. Depois de montar os tabuleiros, é a hora de levar os biscoitos ao forno. Depois de assados, vem o momento mais esperado: compartilhar os deliciosos biscoitos escrevidos e produzidos coletivamente.

$\mathrm{Na}$ avaliação das Escolas Públicas de Araçuaí realizada pelo IDEB, registra-se uma diferença semelhante nos resultados individuais obtidos pelos alunos das escolas parceiras quando comparados com aqueles das não participantes, como verificado em Curvelo, vide Tabela 9. Os resultados, alcançados pelos alunos das escolas parceiras do Projeto Ser Criança - Escola Estadual Prof. Leopoldo Pereira, Escola Estadual Manoel Fulgêncio e Escola Estadual Dom José de Haas foram superiores à média das notas dos alunos do município, à meta projetada pela Secretaria de Educação e ao desempenho dos alunos nas escolas não parceiras - Escola Estadual Isaltina Cajubi Fulgêncio e Escola Estadual Frei Rogato.

Tabela 9 - IDEB Escolas Públicas de Araçuaí: 4ª́rie / $5^{\circ}$ ano

\begin{tabular}{c|c|c|c|c|c}
\hline \multicolumn{2}{c|}{ Município } & \multicolumn{3}{c}{ Escola Estadual } \\
\hline \multirow{2}{*}{ Ano } & $\begin{array}{c}\text { Média } \\
\text { Projetada }\end{array}$ & $\begin{array}{c}\text { Média } \\
\text { Verificada }\end{array}$ & $\begin{array}{c}\text { Prof. Leopoldo } \\
\text { Pereira }\end{array}$ & $\begin{array}{c}\text { Manoel } \\
\text { Fulgêncio }\end{array}$ & $\begin{array}{c}\text { Isaltina Cajubi } \\
\text { Fulgêncio }\end{array}$ \\
\hline 2005 & - & 4,2 & 4,2 & 4,3 & 3,8 \\
2007 & 4,3 & 4,1 & 4,7 & 3,9 & 4,1 \\
2009 & 4,6 & 5,3 & 5,6 & 5,2 & 4,7 \\
2011 & 5,0 & 5,3 & 5,8 & 5,1 & 4,5 \\
2013 & 5,3 & 5,6 & 5,8 & 5,0 & 4,4 \\
\hline
\end{tabular}

Fonte: INEP (2015) disponível em http://ideb.inep.gov.br/resultado/home.seam?cid=217621 recuperado em 15 de março de 2015

O resultado, auferido no IDEB pelas escolas públicas de Araçuaí referente à $4^{\mathrm{a}}$ série $/ 5^{\circ}$ ano, merece destaque para a escola parceira do Projeto Leopoldo Pereira que, nas últimas avaliações de 2005 a 2013, alcançou nota igual ou superior à média do município e escore superior à meta que lhe fora projetada conforme descrito na tabela 10 . Segundo uma das educadoras entrevistadas, esses melhores resultados no IDEB devem ser, também, debitados em parte às atividades pedagógicas desenvolvidas com os alunos das escolas parcerias do Projeto. Destacam-se entre elas: as oficinas de 
jogos de matemática, as rodas de contação de histórias, apresentações do coral e oficinas oferecidas aos professores com temas variados pelos educadores e parceiros do CPCD.

Tabela 10 - Taxa de aprovação nas Escolas Públicas de Araçuaí: $4^{\mathrm{a}}$ série / $5^{\circ}$ ano

\begin{tabular}{|c|c|c|c|c|}
\hline \multirow[b]{2}{*}{ Ano } & \multirow{2}{*}{$\begin{array}{c}\text { Taxa Média de } \\
\text { Aprovação no } \\
\text { Município }\end{array}$} & \multicolumn{3}{|c|}{ Escola Estadual } \\
\hline & & $\begin{array}{c}\text { Prof. Leopoldo } \\
\text { Pereira }\end{array}$ & $\begin{array}{c}\text { Manoel } \\
\text { Fulgêncio }\end{array}$ & $\begin{array}{c}\text { Isaltina Cajubi } \\
\text { Fulgêncio }\end{array}$ \\
\hline 2005 & 92,2 & 83,7 & 92,4 & 90,5 \\
\hline 2007 & 91,6 & 94,3 & 82,9 & 92,4 \\
\hline 2009 & 98,8 & 99,2 & 96,9 & 99,6 \\
\hline 2011 & 99,5 & 100 & 98,5 & 99,3 \\
\hline 2013 & 99,7 & 100 & 99,5 & 99,5 \\
\hline
\end{tabular}

Fonte: INEP (2015) disponível em http://ideb.inep.gov.br/resultado/home.seam?cid=217621 recuperado em 15 de março de 2015

A taxa de aprovação nas escolas de Araçuaí tem crescido desde o ano de 2005. A escola parceira Leopoldo Pereira, por exemplo, conseguiu $100 \%$ de aprovação dos alunos da $4^{\mathrm{a}}$ série $/ 5^{\circ}$ ano em $2011 \mathrm{e}$ 2013 (Tabela 11). Esse bom desempenho relacionase às ações implementadas pelo Projeto, ao dedicar uma parte dos encontros diários ao clubinho da matéria, onde são trabalhadas com os alunos suas dificuldades principais em língua portuguesa e matemática, por meio de livros, textos, jogos, dinâmicas e brincadeiras, construção de histórias e vários outros instrumentos educativos que possibilitam ao aluno a superação das suas deficiências pedagógicas.

Tabela 11- Nota de Matemática na Prova Brasil nas Escolas Públicas de Araçuaí: $8^{\text {a }}$ série / $9^{\circ}$ $9^{\circ}$ ano

\begin{tabular}{c|c|c|c|c}
\hline \multirow{2}{*}{ Ano } & \multirow{2}{*}{$\begin{array}{c}\text { Média na Nota } \\
\text { de Matemática } \\
\end{array}$} & \multicolumn{3}{|c}{ Escola Estadual } \\
\cline { 3 - 5 } & no Município & $\begin{array}{c}\text { Prof. Leopoldo } \\
\text { Pereira }\end{array}$ & $\begin{array}{c}\text { Dom José de } \\
\text { Haas }\end{array}$ & Frei Rogato \\
\hline 2005 & 233,60 & 248,51 & 226,76 & 219,05 \\
2007 & 241,15 & 245,62 & 231,57 & 239,69 \\
2009 & 249,78 & 248,67 & 242,33 & 242,62 \\
2011 & 255,98 & 264,22 & 246,58 & 253,44 \\
2013 & 250,78 & 256,35 & 231,16 & 250,95 \\
\hline
\end{tabular}

Fonte: INEP (2015) disponível em http://ideb.inep.gov.br/resultado/home.seam?cid=217621 recuperado em 15 de março de 2015

A nota de matemática na prova Brasil da $8^{a}$ série / $9^{\circ}$ ano dos alunos da escola parceira Leopoldo Pereira superou a média do município em todas as provas, exceto no ano de 2009, quando seus resultados ficaram abaixo da média das notas dos alunos do município. (Tabela 12). Novamente, destaca-se a educação integral ministrada pelo
Projeto que ensina por meio de recursos disponíveis na comunidade. $\mathrm{O}$ aprendizado de matemática no Projeto, por exemplo, tem sido estimulado na cozinha experimental, onde as crianças participam da preparação de uma receita, aprendendo a separar e cortar a quantidade de ingredientes de cada item da receita.

Tabela 12 - Nota de Língua Portuguesa na Prova Brasil nas Escolas Públicas de Araçuaí: $8^{\mathrm{a}}$ série $/ 9^{\circ}$ ano

\begin{tabular}{c|c|c|c|c}
\hline \multirow{2}{*}{ Ano } & \multirow{2}{*}{$\begin{array}{c}\text { Média na Nota de } \\
\text { Língua Portuguesa } \\
\text { no Município }\end{array}$} & $\begin{array}{c}\text { Escola Estadual } \\
\text { Pereira }\end{array}$ & $\begin{array}{c}\text { Dom José de } \\
\text { Haas }\end{array}$ & \multirow{2}{*}{ Frei Rogato } \\
\hline 2005 & 220,00 & 231,36 & 213,79 & 210,42 \\
2007 & 228,75 & 236,97 & 217,05 & 225,52 \\
2009 & 251,42 & 259,31 & 242,79 & 241,32 \\
2011 & 250,51 & 263,69 & 238,49 & 242,75 \\
2013 & 248,47 & 252,08 & 232,32 & 252,32 \\
\hline
\end{tabular}

Fonte: INEP (2015) disponível em http://ideb.inep.gov.br/resultado/home.seam?cid=217621 recuperado em 15 de março de 2015 
Os resultados dos exames da $8^{\mathrm{a}}$ série $/ 9^{\circ}$ ano da escola parceira Leopoldo Pereira nas cinco avaliações feitas pela prova Brasil de 2005 até 2013 na disciplina de língua portuguesa superaram a nota média do município de acordo com a tabela 12. Nela, os conteúdos de língua portuguesa foram abordados de formas diferentes, por meio das rodas de contação de histórias, que ajudou a estimular a interpretação e a criatividade de cada participante, pois as histórias contadas são escolhidas com a intenção de estimular a aprendizagem de forma lúdica e prazerosa.

A melhora dos resultados na educação em Araçuaí reflete a contribuição positiva dado pelo Projeto ao longo do período. Em 2014, por exemplo, o Projeto programou diversas ações, por meio de seus oito educadores, que atenderam 163 crianças no período da manhã e da tarde. Entre elas, devem-se destacar: a realização da colônia de férias, promovida nas férias escolares de julho; as viagens do coral dos Meninos de Araçuaí, para fazer apresentações em várias cidades brasileiras; as diversas oficinas de música, de jogos, de cuidados com o jardim, de cartões de tinta de terra, de percussão e de argila.

\subsection{Dados Comparativos entre os dois Projetos}

Uma análise comparativa entre os dois Projetos permite que se identifiquem semelhanças e diferenças entre eles. Suas semelhanças residem na sua concepção filosófica e nas pedagogias e diretrizes educativas adotadas. No entanto, o modo de implementá-los, as ênfases dadas pelos educadores, o interesse e a participação dos alunos são aspectos importantes entre outros, sempre diferenciados no seu desempenho em função da individualidade, comprometimento e motivação de cada um.

Em Curvelo, é perceptível a preferência dos alunos pelos jogos e pelo piquenique literário. Lá foi registrada a criação dos 168 jogos catalogados pelo CPCD, divididos em três coleções: Bornalzinho de Jogos, Bornal de Jogos e Bornal da Paz. Próxima à sede do Projeto em Curvelo tem uma praça, onde era feito o piquenique literário, uma atividade que as crianças gostavam de participar.

Já em Araçuaí, o destaque maior tem sido a música e as atividades de rua empreendidas. As crianças gostam muito de música, sendo escolhidas algumas para participar do Coral Meninos de Araçuaí que surgiu após uma apresentação das crianças do Projeto para agradecer a parceria com a empresa Natura. As crianças quando chegam ao Projeto ficam brincando nos espaços do Projeto, mas quando as educadoras sentam na roda e começam a cantar logo em seguida todas as crianças ocupam seus lugares e incorporam-se às atividades em andamento.

Tabela 13- Taxa de aprovação nas Escolas Públicas de Araçuaí e Curvelo: $4^{\text {a }}$ série $/ 5^{\circ}$ ano

\begin{tabular}{c|c|c|c|c|c|c}
\hline \multirow{2}{*}{ Ano } & \multicolumn{3}{|c|}{ ARAÇUAÍ } & \multicolumn{3}{c}{ CURVELO } \\
\cline { 2 - 7 } & \multicolumn{3}{|c|}{ Escola Estadual } & \multicolumn{3}{c}{ Escola Municipal } \\
\cline { 2 - 7 } & $\begin{array}{c}\text { Prof. } \\
\text { Leopoldo } \\
\text { Pereira }\end{array}$ & $\begin{array}{c}\text { Manoel } \\
\text { Fulgêncio }\end{array}$ & $\begin{array}{c}\text { Isaltina } \\
\text { Cajubi } \\
\text { Fulgêncio }\end{array}$ & $\begin{array}{c}\text { Dr. Viriato } \\
\text { Diniz } \\
\text { Mascarenhas }\end{array}$ & $\begin{array}{c}\text { Antônio Diniz } \\
\text { Couto` }\end{array}$ & $\begin{array}{c}\text { Filomena de } \\
\text { Oliveira Leite }\end{array}$ \\
\hline 2005 & 83,7 & 92,4 & 90,5 & 80,5 & 88,8 & 87,5 \\
2007 & 94,3 & 82,9 & 92,4 & 82,4 & 90,9 & 91,0 \\
2009 & 99,2 & 96,9 & 99,6 & 86,7 & 87,5 & 96,4 \\
2011 & 100 & 98,5 & 99,3 & 92,9 & 96,4 & 90,4 \\
2013 & 100 & 99,5 & 99,5 & 97,5 & 95,3 & 93,5 \\
\hline
\end{tabular}

Fonte: INEP (2015) disponível em http://ideb.inep.gov.br/resultado/home.seam?cid=217621 recuperado em 15 de março de 2015

Entre as seis escolas estudadas nas duas cidades, os alunos da escola Leopoldo Pereira de Araçuaí obtiveram os melhores resultados na taxa de aprovação da $4^{\mathrm{a}}$ série $/ 5^{\circ}$ ano de 2007 até 2013 , com destaque para 2011 e 2013 quando auferiram a nota máxima $(100,0)$ (Tabela 13). Essas notas foram obtidas com muito esforço e dispêndio devido à parceria entre o Projeto e a Escola. A diretora da escola tem um bom relacionamento com as educadoras do Projeto. Por isto, são desenvolvidas várias ações de integração nas duas escolas durante o ano: oficinas de jogos, músicas e percussão; roda de contação de história; e apresentação do coral. 
Tabela 14 - Nota de Matemática na Prova Brasil nas Escolas Públicas de Araçuaí e Curvelo: $8^{a}$ série / $9^{\circ}$ ano

\begin{tabular}{c|c|c|c|c|c|c}
\hline \multirow{2}{*}{ Ano } & \multicolumn{3}{|c|}{ ARAÇUAÍ } & \multicolumn{3}{c}{ CURVELO } \\
\cline { 2 - 7 } & \multicolumn{3}{|c|}{ Escola Estadual } & \multicolumn{3}{c}{ Escola Estadual } \\
\cline { 2 - 7 } & $\begin{array}{c}\text { Prof. } \\
\text { Peopoldo }\end{array}$ & $\begin{array}{c}\text { Dom José } \\
\text { de Haas }\end{array}$ & $\begin{array}{c}\text { Frei } \\
\text { Rogato }\end{array}$ & $\begin{array}{c}\text { Interventor } \\
\text { Alcides Lins }\end{array}$ & $\begin{array}{c}\text { Ministro } \\
\text { Adauto Lúcio } \\
\text { Cardoso }\end{array}$ & $\begin{array}{c}\text { São Vicente de } \\
\text { Paulo }\end{array}$ \\
\hline 2005 & 248,51 & 226,76 & 219,05 & 247,45 & 247,09 & 252,27 \\
2007 & 245,62 & 231,57 & 239,69 & 252,27 & 236,31 & 226,53 \\
2009 & 248,67 & 242,33 & 242,62 & 260,65 & 236,59 & 231,63 \\
2011 & 264,22 & 246,58 & 253,44 & 264,28 & 234,64 & 230,16 \\
2013 & 256,35 & 231,16 & 250,95 & 271,62 & 256,06 & 231,10 \\
\hline
\end{tabular}

Fonte: INEP (2015) disponível em http://ideb.inep.gov.br/resultado/home.seam?cid=217621 recuperado em 15 de março de 2015

Os alunos das escolas parceiras Interventor Alcides e Leopoldo Pereira - obtiveram os melhores resultados na nota de matemática da $8^{\mathrm{a}}$ série / $9^{\circ}$ ano. (Tabela 14). Na entrevista com o aluno Kildary de 11 anos da Leopoldo Pereira, pode-se notar a importância dos jogos no seu aprendizado: "É possível aprender brincando, as brincadeiras ajudam bastante, têm jogos de matemática e de memória que nos ajudam a aprender a fazer as continhas". O aluno Thalison de 13 anos da mesma, quando chegou ao Projeto, havia sido reprovado no $6^{\circ}$ ano e não conseguia aprender as contas de multiplicação. A educadora Léia utilizou uma das técnicas inovadoras construídas no Projeto, a damática, para que ele aprendesse a multiplicar. $\mathrm{O}$ resultado foi surpreendente, pois, além dele conseguir aprender a multiplicar, levou o jogo para os seus colegas da escola pública para que eles também a aprendessem.

Fazendo-se uma avaliação ex-post dos resultados do Projeto Ser Criança de Araçuaí, podese concluir que as ações feitas pelos educadores do Projeto contribuíram significativamente para melhorar o desempenho dos alunos que estudam em tempo integral, com base nos exames realizados pelo IDEB. Depois de ter constatado que os resultados alcançados pelos egressos têm sido satisfatórios, pode-se recomendar a continuidade do Projeto Ser Criança pelas suas contribuições ao melhoramento da aprendizagem de alunos de educação fundamental participantes das escolas públicas de Curvelo e Araçuaí.

\section{CONSIDERAÇÕES FINAIS}

Este artigo teve como objetivo geral avaliar o Projeto Ser Criança "Educação pelo Brinquedo", implementado em Curvelo e Araçuaí, analisando os resultados por ele produzidos no sentido da formação social de crianças e adolescentes dele participantes. A avaliação de projetos, conforme explicam Carvalho (2003) e Januzzi (2012), encerra uma atividade fundamental na medida em que possibilitam a visualização dos resultados obtidos.

Reafirma-se a positividade do Projeto pelos resultados educativos alcançados na formação social das crianças e dos adolescentes de sete a quatorze anos, residentes em áreas classificadas como de risco social nas escolas parceiras nas duas cidades mencionadas. A parceria do Projeto com a escola pública forneceu aos seus alunos uma experiência de escola integral com atividades educativas inovadoras por ele desenvolvidas com base no resgate de traços culturais regionais importantes pelas cinco Pedagogias com ênfase na pedagogia da roda, na criação e uso de jogos, no estímulo à leitura e ao desenvolvimento musical. Dessa estratégia advém sua maior eficácia na socialização, na formação da cidadania e no melhoramento escolar das crianças e dos adolescentes participantes.

A despeito dessa base comum, ao comparar os resultados obtidos em Curvelo e Araçuaí, percebem-se efeitos semelhantes como um melhoramento escolar dos alunos das escolas parceiras da $4^{\mathrm{a}}$ série $/ 5^{\circ}$ ano e da $8^{\mathrm{a}}$ série $/ 9^{\circ}$ ano em matemática e português. Mas há também diferenças de ênfase nos resultados produzidos porque a essência de projeto educacional não repousa necessariamente na sua concepção pedagógica, mas, como toda atividade humana, supõe o fazer e o querer dos atores envolvidos. Por isto, na visita feita a Araçuaí, foi possível verificar que existe um comprometimento maior por parte das crianças até 11 anos com as atividades do Projeto, em comparação com os adolescentes de 11 a 14 anos, que demonstraram menor interesse em participar de algumas atividades propostas, como a colônia de férias que se realiza em julho.

A Escola parceira Leopoldo Pereira recebe a maioria dos alunos do Projeto em Araçuaí devido à sua localização próxima à sede. Ao analisar seus resultados, percebe-se que eles foram mais positivos, porque superiores à nota média das escolas de Araçuaí e Curvelo, outra comprovação da eficácia do Projeto na melhoria da aprendizagem, com a 
utilização dos métodos da educação integral e das pedagogias inovadoras. Vale destacar que a parceria de sucesso existente entre o Projeto e a Escola Leopoldo Pereira deve ser seguida como referência para alcançar melhores resultado na educação de Minas Gerais e do Brasil.

O exame dos resultados do IDEB dos alunos de Curvelo permite que se conclua que os alunos das escolas parceiras do Projeto auferiram melhores resultados em comparação com aqueles obtidos pelas escolas não parceiras. No entanto, quando se comparam os seus resultados com a média de todas as escolas do município, percebe-se que as escolas parceiras ainda precisam melhorar $\mathrm{o}$ rendimento educacional dos seus alunos com base nas notas da prova Brasil em matemática e língua portuguesa, aumentando sua taxa de aprovação. Em Araçuaí, a parceira do Projeto com a escola pública Leopoldo Pereira possibilitou que quase todos os seus alunos alcançassem uma nota superior à média dos alunos das demais escolas públicas do município. Isto demonstra a influência positiva do Projeto na educação das crianças e os adolescentes.

Uma limitação da pesquisa foi a falta dos resultados das avaliações do IDEB nos anos de 1989 a 2004 na cidade de Curvelo e de 1998 a 2004 em Araçuaí e dos relatórios técnicos nos anos de 1989 a 2001 na cidade de Curvelo e de 1998 a 2001 em Araçuaí, tornando menos rica a nossa avaliação dos dois projetos. A partir dos resultados obtidos sugerem-se futuras pesquisas envolvendo outros projetos sociais e outras regiões do país. Nesse sentido, conforme Albuquerque (2006) e Jannuzzi (2014), seria interessante adotar uma perspectiva interdisciplinar já que projetos envolvem esforços de gestão por resultados e conflitos derivados das diferentes racionalidades inerentes ao processo de decisão, planejamento e implementação.

\section{REFERÊNCIAS}

Albuquerque, A. C. C. (2006). Terceiro setor: história e gestão de organizações. São Paulo: Summus.

Barros, R. P. \& Lima, L. (2012). Avaliação de impacto de programas sociais: por que, para que e quando fazer? In: Menezes, N. Filho (Org.). Avaliação econômica de projetos sociais. (pp. 1329). São Paulo: Dinâmica.

Carvalho, M. C. B. de (2001). Avaliação de projetos sociais. In: Ávila, C. M. de. (coord). Gestão de projetos sociais ( $3^{\text {a }}$ ed.). (pp. 59-89). São Paulo: AAPCS - Associação de Apoio ao Programa Capacitação Solidária - (Coleção gestores sociais)
Carvalho, S. N. (2003). Avaliação de programas sociais balanço das experiências e contribuição para o debate. São Paulo em Perspectivas: São Paulo, 17(3-4), 185-197.

Cohen, E. \& Franco, R. (2012). Avaliação de projetos sociais. ( $10^{\mathrm{a}} \mathrm{ed}$.). Petrópolis: Vozes.

Constituição da República Federativa do Brasil de 1988. Recuperado em 26 de fevereiro, de 2015, de http://www.planalto.gov.br/ccivil_03/constituicao/c onstituicao.html

Drucker, P. (2002). Administração de organizações sem fins lucrativos: princípios e práticas (N. Montingelli Jr. Trad.). São Paulo: Thomson. (Obra original publicada em 2001).

Gil, A. C. (2008). Métodos e Técnicas de Pesquisa Social. (6 $6^{\mathrm{a}}$ ed.). São Paulo: Atlas.

Giroletti, D. A. (2009). Crise econômica mundial e mudança na estratégia de desenvolvimento. In: Paula, C. P. A. \& Moraes, L. F. R. (Org.). Administração contemporânea: desafios e controvérsias. (pp. 11-30). Fundação Cultural Dr. Pedro Leopoldo: Tavares.

Giroletti, D. A., Lima, R. J. C. \& Patah, L. A. (2012 Set/Dez). Educação para inovação. Revista Administração UFSM: Santa Maria, 5(3), 607-624.

Goergen, P. (2005). Prefácio. In: Dias Sobrinho, J. Dilemas da educação superior no mundo globalizado: sociedade do conhecimento ou economia do conhecimento? (pp. 11-19). São Paulo: Caso do Psicólogo.

Goergen, P. (2014 nov.). Tecnociência, pensamento e formação na educação superior. Revista de Avaliação da Educação Superior: Campinas, Sorocaba, 19(3), 561-584.

Grayson, D. \& Hodges, A. (2002). Compromisso social e gestão empresarial. (C. M. Rosa, C. Taylor \& M. Tambelli Trad.). São Paulo: Publifolha. (Obra original publicada em 2001).

Guba,E.G. \& Lincoln, Y.S. (2011). Avaliaçao de Quarta Geraçao (Beth Honorato Trad.).Campinas, SP: Editora da UNICAMP.

Jannuzzi, P. M. (2014, Maio/Ago.) Avaliação de programas sociais: conceitos e referenciais de quem a realiza. Revista EAE - Estudos em Avaliação Educacional. São Paulo, SP: Fundação Carlos Chagas. 25(58), 22-42. 
Jannuzzi, P. M. (2013, Jan/Jun.) Sistema de monitoramento e avaliação de programas sociais: revisitando mitos recolocando premissas para sua maior efetividade na gestão. Revista Brasileira de Monitoramento e Avaliação. Brasília, DF: Ministério de Desenvolvimento social e combate à fome. Secretaria de Avaliação. 5(1), 04-27.

Kliksberg, B. (2010). Os desafios éticos de um continente paradoxal. In: Sen, A. \& Kliksberg, B. As pessoas em primeiro lugar, a ética do desenvolvimento e os problemas do mundo globalizado. (B. Ajzemberg \& C. E. L. Silva, Trad.). (pp. 137-354). São Paulo: Companhia das Letras. (Obra original publicada em 2007).

Kliksberg, B. (1998). Repensando o estado para o desenvolvimento social: superando dogmas e convencionalismos. (J. O. P. da Silva, Trad.). São Paulo: Cortez. (Obra original publicada em 1998).

Marino, E. (2003a). Manual de avaliação de projetos sociais. (2 $2^{\mathrm{a}}$ ed.). São Paulo: Saraiva.

Marino, E. (2003b). Diretrizes para avaliação de projetos e programas de investimento social privado: estudo da aplicabilidade dos Standards de Avaliação de Programas definidos pelo The Joint Committee of Standards for Education Evaluation em programas e projetos de investimento social privado. USP (Dissertação de Mestrado), pág. 197.

Pio, C. A. \& Czernisz, E. C. S. (2015, Jan/Abr.). A educação integral no mais educação: uma análise do programa. Educação (UFSM): Santa Maria, 40(1), 241-254.
Raposo, R. (2001). Avaliação de ações sociais: uma abordagem estratégica. In: Ávila, C. M. de. (coord). Gestão de projetos sociais ( $3^{a}$ ed.). (pp. 90-101). São Paulo: AAPCS - Associação de Apoio ao Programa Capacitação Solidária - (Coleção gestores sociais)

Rocha Jr, Valter M. (2015). Terceiro Setor, Cidadania e Educação Integral: Avaliação do Projeto Ser Criança, Pedro Leopoldo, FPL/MPA (Dissertação de Mestrado), pág. 123.

Sachs, J. (2008). A riqueza de todos. (S. Lamarão Trad.). Rio de Janeiro: Nova Fronteira. (Obra original publicada em 2008).

Sano, H. \& Montenegro Filho, M. J. F. (2013, Jan/Abr.). As técnicas de avaliação da eficiência, eficácia e efetividade na gestão pública e sua relevância para o desenvolvimento social e das ações públicas. Desenvolvimento em questão, 11(22), 3561.

Severo, P. S., Tinoco, J. E. P., Claro, J. A. C. S., Schneider, J. O. \& Yoshitake, M. (2014, Jan/Abr.). Educação corporativa na busca pela construção e vivência de atitudes e valores de cooperação e cidadania voltados ao desenvolvimento regional. Revista de Administração UNIMEP: Piracicaba, 12(1), 159-177.

UNESCO. (2012). Educação: um tesouro a descobrir. ( $7^{\mathrm{a}}$ ed.). São Paulo: Cortez; Brasília: MEC: UNESCO.

Vergara, S. C. (1998). Projetos e Relatórios de Pesquisa em Administração. (2a ed.). São Paulo: Atlas. 